\title{
IAMJ
}

INTERNATIONAL

AYURVEDIC

MEDICAL JOURNAL

\section{EVIDENCE BASED MANAGEMENT OF UPAPLUTA YONIVYAPAD - IN VITRO CASE STUDY REPORT}

\author{
$\underline{\text { Sharada Ambadas Pimpare }}^{1}, \underline{\text { Soudamini Sudhir Chaudhary }}^{2}, \underline{\text { Manjusha Meshram }}^{3}$
}

${ }^{1}$ Streerog \& Prasutitantra Department, Government Ayurved College, Nanded, Maharashtra, India

${ }^{2}$ Guide \& HOD: Streerog \& Prasuti Tantra Department, Government Ayurved College, Nanded, Maharashtra, India

${ }^{3}$ Co-Guide: Streerog \& Prasuti Tantra Department, Government Ayurved College, Nanded, Maharashtra, India

\section{Corresponding Author: pimpare.sharada@gmail.com}

\section{https://doi.org/10.46607/iamj3809042021}

(Published Online: April 2021)

Open Access

(C) International Ayurvedic Medical Journal, India 2021

Article Received: 20/03/2021 - Peer Reviewed: 13/04/2021 - Accepted for Publication: 15/04/2021

Check for updates

\begin{abstract}
Vaginitis is a common problem during pregnancy. Most commonly Candidial vaginitis \& Bacterial vaginitis forms are found. It has hazardous effects on pregnancy like miscarriage, preterm labour etc. Therefore, careful management of patient is necessary. Ayurveda described this condition under Yonivyapad chapter which labelled as Upapluta Yonivyapad which means overflowed vaginal discharge with vaginal itching \& mild abdominal pain. We can correlate Upapluta Yonivyapad with Candidial vaginitis. In this case study we have taken 2 cases of Candidial Vaginitis \& local application of herbal drugs kwath was done. Evidence based beneficial results shown through HPE to the patient of Upapluta Yonivyapad \& is safe during pregnancy. By this we can conclude that the ayurvedic drugs is the best solution to treat vaginitis during pregnancy.
\end{abstract}

Keywords: Vaginitis, Upapluta Yonivyapad.

\section{INTRODUCTION}

Normal vaginal discharge is thin \& clear. During pregnancy due to increased vascularity there is copious \& tenacious vaginal discharge called as physiological leucorrhoea of pregnancy. Vaginitis is common problem during pregnancy. As in pregnancy bacterial \& fungal infection of genital track are increased due to increased cell glycogen \& reduced $\mathrm{pH}$ under the influence of high oestrogen levels. This infection in pregnancy requires 
adequate $\&$ careful management. These infections are dangerous to mother $\&$ fetus as it causes fetal demise, miscarriage \& premature labour.

It was observed that prevalence of Vulvovaginal candidiasis is $36.5 \%$, Bacterial vaginitis is $30.9 \%$ \& Trichomonal vaginitis is $1.4 \%$ in pregnant women.

When it is treated with allopathic medicines the recurrence rate is $30 \%$ at 3 month \& $>50 \%$ by 12 months. Above said observations tell us about that how seriously it should be managed quickly.

While going through ayurvedic texts it was noticed that Ayurveda had elaborated the condition very well during pregnancy with its proper \& safe management. According to Ayurveda vulvovaginitis during pregnancy is labeled as Upapluta Yonivyapada.

Here -

Upapluta meaning is overflowed

Yonivyapada means infection in vagina

The chief management suggested could be in the form of oral \& local application. The herbal drugs those having properties of Ruksha (dry), Tikta (bitter in taste) \& Ushna (hot) must be used. As this vulvovaginitis is with mucoid, thick, sticky discharge these drugs having opposite properties that helps to vanish the discharge locally.

We decided to do pilot study by using combination as for local application. In upapluta yonivyapad because this combination having opposite properties to disease making etiopathology.

It was planned to use trial drug in the form of $D a$ ruharidra powder, Haridra powder by making kwath which mixed in Honey. This herbal combination used as doing vaginal painting two times a day for three days.

\section{Material \& Method}

We have taken cases admitted in our IPD of prasutitantra \& streeroga department in government ayurveda hospital, Nanded. They have complaining of white discharge per vaginum, itching at vagina

Procedure -

- In first patient before starting of treatment by per speculum examination the vaginal discharge of patient was collected in a plain tube by pipette \& equal amount of normal saline added into it .Then this sample was took into pathology laboratory, there smear slide of discharge made \& was observed under the microscope. In that slide we have seen plenty of inflammatory cells \& presence of Yeast like fungus Candida Albicans. Therefore, before application of drug vaginal smear was rich in Candida Albicans so it could be labeled as Vaginal Candidiasis.

Then we started treatment as local application of herbal combination of Haridra powder, Daruharidra powder prepared kwath mixed in honey two times in a day for three days.

- In the second patient we have seen the vaginal discharge smear under microscope which shows Yeast like fungus Candida Albicans. In this smear the number of inflammatory cells were less than previous patient smear.

Also, there were plenty of epithelial cells in this smear. No other bacteria observed.

Post treatment smear seen under microscope which shows that no yeast like fungus in the slide. Also, few inflammatory cells \& plenty of squamous epithelial cells seen. 

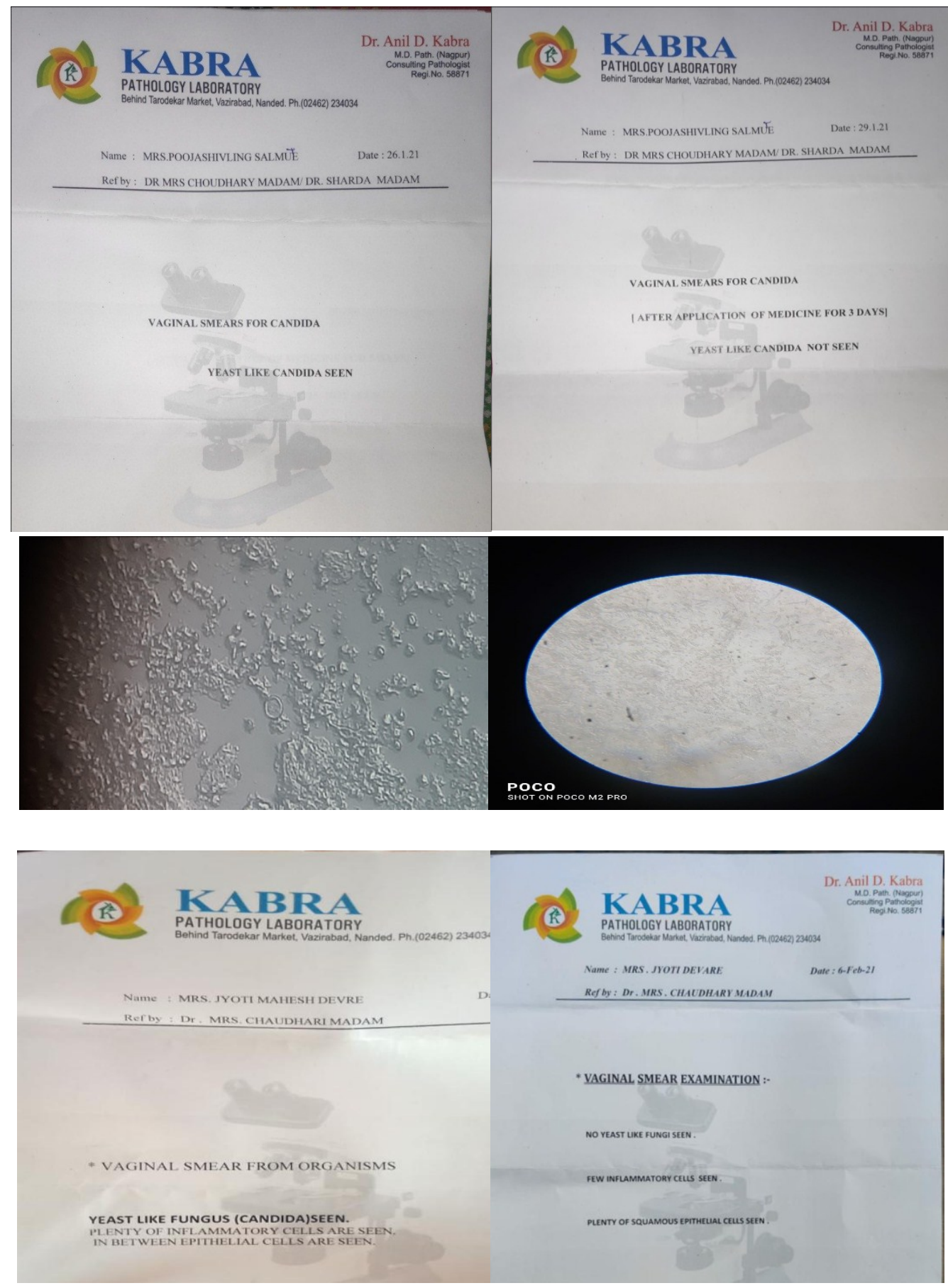

\section{DISCUSSION}

Lots of antifungal creams \& tablets used in modern science are found to be resistance now a days in society. Inadequate intake of antifungal tablets $\&$ creams could be one of the reasons, that's why attraction of this in vitro study was an antifungal not because of that attraction of this study was efficacy of herbal antifungal medicine \& recurrence.

This is in vitro study of 2 cases, it was observed that slide prepared was shown that presence of Candida Albicans in yeast form. After three-day treatment in smear slide yeast was completely absent. 


\section{Ayurvedic etiopathology of Upapluta Yonivyapad:}

This pattern of vaginitis mainly described about fungal vaginal infection during pregnancy. It is named as upapluta yonivyapad according to ancient books. There are mainly 3 symptoms should be taken in consideration

1. Vaginal itching

2. Curdy white discharge

3. Slight lower abdominal pain

According to Ayurveda these 3 symptoms suggest predominance of vitiated kapha in combination with vata dosha. It means that 2 abnormally vitiated dishes namely kappa \& vata are chief causative factor responsible for such type of vaginitis during pregnancy. As this condition during pregnancy could be responsible for premature rupture of membrane, preterm labour are necessary to be treated immediately.

\section{Mode of action of drugs:}

Combination of herbs namely Daruharidra (Berberis aristata), Haridra (Curcuma longa), added with honey is observed as useful combination to vanish the said symptoms of upapluta yonivyapad because of its properties. It resolves symptoms of kaphavata because of opposite properties of kaphavata disease forming properties. Daruharidra \& Haridra helps to minimize amount of discharge with kashaya ras, as astringent it kills active infection with help of tikta, ushna guna. As it is locally applied it cleanses vaginal mucosa with help of cleansing action of honey. In one in vitro study show that honey stops growth of candida albicans.

Chemical composition contains Berberine in $d a$ ruharidra \& Curcumin in haridra. Both are chemically observed as antimicrobial in efficacy \& ultimately antifungal. Curcumin \& Berberine has been reported to have direct antifungal activity against various strains of candida albicans.

\section{CONCLUSION}

This in vitro study concludes that Berberine, Curtain \& honey combination is of antibacterial, antifungal \& non-recurrence in property. $\mathrm{pH}$ of honey is 3.9 therefore it could maintain $\mathrm{pH}$, so it keeps fungal infection up at away.

\section{REFERENCES}

1. Bramhanand Tripathi, Charak Samhita, Chaukhamba Surbharati Prakashan, Varanasi, Chikitsa Sthan Chapter 30

2. Ambikadatta Shastri, Sushruta Samhita, Chaukhamba Sanskrit Sansthan, Varanasi, Uttartantra 38/27

3. D. C. Dutta Textbook of Gynecology Edited by Hiralal Konar.

4. http://bmcpregnancychildbirth.biomedcentral.com

5. www.contemporaryobgyn.net/view/recurrent vulvovaginitis

6. Vaidya V. M. Gogte, Ayurvedic pharmacology \& therapeutic uses of medicinal plants (Dravyagunavigyan) page no. 395

7. Vaidya V. M. Gogte, Ayurvedic pharmacology \& therapeutic uses of medicinal plants (Dravyagunavigyan) page no. 514

8. www.ncbi.nlm.nih.gov/pmc/articles

9. www.healthline.com

\section{Source of Support: Nil}

\section{Conflict of Interest: None Declared}

How to cite this URL: Sharada Ambadas Pimpare: Evidence Based Management Of Upapluta Yonivyapad - In Vitro Case Study Report. International Ayurvedic Medical Journal \{online\} 2021 cited April, 2021\} Available from: http://www.iamj.in/posts/images/upload/909 912.pdf 